\title{
The relationship between serum lysozyme activity and reproductive performance in turkeys
}

\author{
Izabela Prusinowska' and J. Jankowski \\ ${ }^{1}$ Department of Genetics and Animal Improvement \\ ${ }^{2}$ Department of Poultry Science \\ Olsztyn University of Agriculture and Technology \\ 10-718 Olsztyn 5, Poland
}

(Received 20 May 1996; accepted 13 September 1996)

\begin{abstract}
Studies were carried out in order to determine the dynamics of changes in lyso/yme activity in the serum of turkey females during the laying period, and to identify the relationship between lysozyme activity and utility parameters. The experiments were carried out on 107 randomly chosen females from a maternal female strain (J-44), selected to increase egg production. Lysozyme activity was determined four times, in the $6 \mathrm{th}, 12 \mathrm{th}, 18$ th and 24th weck of the laying period. Lysozyme activity was found to increase significantly in the 12 th week. followed by a subsequent, gradual decrease. In the $18 \mathrm{th}$ weck of the laying period, a signilicant negative correlation was found between lysozyme activity and the number of laid eggs and hatchability, and a significant positive correlation between lysozyme activity and percentage of unhatched poults. Correlation betwcen lysozyme activity and reproductive performance in other periods was low and insignificant.
\end{abstract}

KEY WORDS: turkeys, lysozyme activity, reproductive performance

\section{INTRODUCTION}

Non-specific immunity represents the first defense of an organism against a variety of pathogenic factors. Lysozyme, an enzyme which is able to disrupt peptidoglycans in bacterial cell walls, is an important component of humoral non specific immunity. Hydrolytic properties of the enzyme destroy Gram-positive bacteria, and together with the complement and immunoglobulins also Gram-negative ones (Jollés and Jollés, 1984; Kowalska and Rzedzicki, 1988). The 
significant role of lysozyme in defense mechanisms suggests its applicability as an index of non-specific immunity of domestic animals. Indirect selection makes it possible to eliminate the risk and costs related to animal exposure to pathogenic antigens. However, it should be underlined that a potential marker of the defense functions of an organism should not be negatively correlated with the most important production traits. In preliminary studies (Jankowski et al., 1994) carried out on turkey hens in the 17th week of the laying period, a negative correlation was found between lysozyme activity and some reproductive performance measures. If selection is to be based on lysozyme activity, it is important to determine if this correlation is a consistent phenomenon, or if it was incidental, resulting from overburdening caused by the egg laying process.

The objective of this study was to determine the dynamics of changes in lysozyme activity in turkey hens over different stages of the laying period, and to assess the relationship between enzyme activity and utility traits.

\section{MATERIAL AND METHODS}

The studics cncompassed 107 randomly chosen turkey hens from a female maternal strain (J-44), selected to increase egg production in the Turkey Breeding Station in Biesal. The birds were weighed at the age of 30 and 56 weeks. In addition to this, the following were determined individually: age at reproductive maturity (laying of the first egg), number of laying days, number of eggs and broodiness. Egg fertility, number of dead embryos up to day 10 of incubation, number of unhatched poults, number of abnormal and healthy poults from set and fertile eggs were determined during hatching.

Blood for determination of lysozyme activity was collected four times (at 6 -week intervals) in the $6 \mathrm{th}, 12 \mathrm{th}, 18 \mathrm{th}$ and $24 \mathrm{th}$ week of the laying period, i.e. in the 38 th, 44 th, 50 th and 56 th week of life, respectively. Serum lysozyme activity

TABLE 1

Characteristics of the level and variations of lysozyme activity

\begin{tabular}{cccc}
\hline $\begin{array}{c}\text { Laying period, } \\
\text { week }\end{array}$ & $\overline{\mathrm{x}}, \mathrm{mg} / \mathrm{l}$ & $\begin{array}{c}\text { Statistical measures } \\
\mathrm{s}, \mathrm{mg} / \mathrm{l}\end{array}$ & $\mathrm{v}, \% \mathrm{w}$ \\
\hline 6 & $3.30^{\mathrm{A}}$ & 0.97 & 29.4 \\
12 & $4.17^{\mathrm{B}}$ & 1.29 & 31.1 \\
18 & $4.13^{\mathrm{B}}$ & 1.75 & 42.4 \\
24 & $3.96^{\mathrm{B}}$ & 1.38 & 34.8 \\
$\mathrm{x}$ & 3.88 & 0.80 & 20.6 \\
\hline
\end{tabular}

within the column mean with different superscripts differ significantly at $\mathrm{P}<0.01$ 
was determined turbidimetrically according to the general procedures described by Metzger (1970). A suspension of lyophilized Micrococcus lysodeicticus cells in $0.067 \mathrm{M}$ phosphate buffer, $\mathrm{pH} 6.8$, in $0.1 \% \mathrm{NaCl}$ solution was used as the substrate. The lytic activity of the enzyme was measured as the decrease of optic density at $540 \mathrm{~nm}$, following $10 \mathrm{~min}$ incubation in $37^{\circ} \mathrm{C}$. The lytic activity of the enzyme was calculated based on a standard curve and expressed in mg of crystalline chicken egg white lysozyme.

The results were analyzed statistically by phenotypic correlation analysis and unifactorial analysis of variance in a non-orthogonal system.

\section{RESULTS}

Average values and dispersion measures of lysozyme in particular periods of the studies are presented in Table 1. A highly significant increase of lysozyme activity was observed in the 12 th week of the laying period. This activity decreased slightly in the subsequent periods.

Table 2 presents the correlation coefficients between enzyme activity in particular periods and activity for the whole period (arithmetic mean from 4 determinations of lysozyme activity). Statistically significant correlation was found between levels of activity in weeks 12 and 18. The highest value of the correlation cocfficient with the activity for the whole laying period was obtained for lysozyme activity measured in the 18 th week.

Mean values of utility traits, and phenotypic relationships between lysozyme activity for the whole laying period and these traits are presented in Table 3. Significant negative correlation between lysozyme activity was found with the number of eggs $(P<0.05)$, poults hatching from set and fertile eggs $(P<0.01)$, while a significant positive correlation was with the percentage of unhatched poults $(\mathrm{P}<0.05)$.

TABLE 2

Correlation betwen lysozyme activity measured in different weeks of the laying period and its mean value for the whole pcriod

\begin{tabular}{ccccc}
\hline Measurement period & 6 & 12 & 18 & 24 \\
\hline 6 & - & & & \\
12 & 0.02 & - & & \\
18 & 0.07 & $0.21^{x}$ & - & - \\
24 & 0.18 & 0.08 & 0.19 & $0.63^{\mathrm{kx}}$ \\
\hline
\end{tabular}

$\mathrm{x}-\mathrm{P}<0.05 ; \mathrm{xx}-\mathrm{P}<0.01$ 
TABLE 3

Mean values of utility traits and correlation betwen lysozyme activity (mean for the whole laying period) and these traits

\begin{tabular}{|c|c|c|}
\hline Specification of analysed traits & $\overline{\mathrm{x}}$ & $\tau$ \\
\hline Body wcight at the age of 30 wecks, $\mathrm{kg}$ & 7.90 & -0.061 \\
\hline 56 weeks, $\mathrm{kg}$ & 8.88 & -0.124 \\
\hline Reproduction maturity, days & 239.56 & 0.040 \\
\hline Broodiness number & 0.30 & 0.133 \\
\hline Number of broodiness, days & 3.29 & 0.129 \\
\hline Number of laying, days & 147.39 & -0.170 \\
\hline Number of eggs & 99.56 & $-0.225^{x}$ \\
\hline Fertility of eggs, \% & 89.09 & -0.136 \\
\hline Embryo mortality till day 10 of the incubation, $\%$ & 7.60 & 0.056 \\
\hline Unhatched poults, $\%$ & 19.54 & $0.243^{x}$ \\
\hline Deformed poults, $\%$ & 6.87 & 0.198 \\
\hline Hatching from fertile eggs, $\%$ & 65.99 & $-0.289^{x x}$ \\
\hline Hatching from set eggs, $\%$ & 58.82 & $-0.297^{\mathrm{xx}}$ \\
\hline Number of poults from one hen & 51.53 & -0.211 \\
\hline
\end{tabular}

$\mathrm{x}-\mathrm{P}<0.05 ; \mathrm{xx}-\mathrm{P}<0.01$

Confirmation of the disadvantageous inter-relationships of lysozyme with the above mentioned characters was oblained from variance analysis, in which differentiation of the mean lysozyme activity for the whole laying period was taken as the variable factor: $\mathrm{L}-$ low $(<\mathrm{x}-0.5 \mathrm{SD}), \mathrm{M}-$ moderate $(\mathrm{x} \pm 0.5 \mathrm{SD})$ and $\mathbf{H}$ - high $(>x+0.5 \mathrm{SD})$ (Table 4$)$. Females in group $\mathrm{H}$ compared to those in group $\mathrm{L}$ were characterized by a lower number of eggs, lower hatchability from set and fertile eggs, and higher percentage of unhatched poults $(\mathrm{P}<0.05)$.

Since considerable changes in lysozyme activity occurred during the course of the laying period, correlation coefficients ( $r$ ) were calculated between consecutive enzyme measurements and values of the traits showing significant corrclation with lysozyme activity for the whole period (Table 5). The highest and statistically significant $r$ values were found in the 18 th week of the laying period. In the other periods, the correlation were low and statistically insignificant.

TABLE 4

The effect of lysozyme activity on the differentiation of reproductive performance

\begin{tabular}{|c|c|c|c|c|}
\hline \multirow{2}{*}{ Trait } & \multicolumn{3}{|c|}{ Groups } & \multirow{2}{*}{$\begin{array}{l}\text { Significance } \\
\text { of differences }\end{array}$} \\
\hline & L & M & $\mathbf{H}$ & \\
\hline Number of eggs & 105.41 & 98.80 & 95.08 & $\mathrm{H}<\mathrm{L}^{\mathrm{x}}$ \\
\hline Unhatched poults, $\%$ & 14.33 & 19.75 & 24.52 & $\mathrm{H}>\mathrm{L}^{\mathrm{x}}$ \\
\hline Hatching from Certile eggs, \% & 70.23 & 67.56 & 58.26 & $\mathrm{H}<\mathrm{L}^{\mathrm{x}}$ \\
\hline Hatching from set eggs, $\%$ & 64.41 & 62.06 & 49.79 & $H<L^{x}$ \\
\hline
\end{tabular}

$\mathrm{x}-\mathrm{P}<0.05$ 
TABELA 5

Correlation betwen lysozyme activity in the consecutive periods of measurements and reproductive performance

\begin{tabular}{lcccr}
\hline \multirow{2}{*}{ Trait } & \multicolumn{4}{c}{ Correlation coeffcient in the weeks of laying } \\
\cline { 2 - 5 } & 6 & 12 & 18 & \multicolumn{1}{c}{24} \\
\hline Number of eggs & 0.171 & -0.074 & $-0.305^{\mathrm{xx}}$ & -0.175 \\
Unhatched poults & 0.045 & 0.100 & $0.199^{\mathrm{x}}$ & 0.185 \\
Hatching from fertile eggs & -0.052 & -0.166 & $-0.301^{\mathrm{x}}$ & -0.147 \\
Hatching firom set eggs & -0.030 & $-0.209^{\mathrm{x}}$ & $-0.312^{\mathrm{kx}}$ & -0.118 \\
Number of poults & -0.104 & -0.136 & $-0.212^{\mathrm{x}}$ & -0.052 \\
\hline
\end{tabular}

$\mathrm{X}-\mathrm{P}<0.05 ; \mathrm{Xx}-\mathrm{P}<0.01$

\section{DISCUSSION}

Lysozyme activity measurements performed four times during the laying period revealed that this parameter varied considerably. A significant increase in activity was observed in the 12th week, indicating that immune processes intensified in this period. An increase of lysozyme activity has been observed in the course of diseases, especially those in which there is an increase of the number of cells containing lysozyme (Kowalska and Rzedzicki, 1988). The highest variability of the enzyme $(v=42.4 \%)$ noted in the 18 th week (Table 1$)$, as well as significant correlation found only between the activities in 12th and 18th week (Table 2), point to different causes of the variability of lysozyme activity in the middle part of the laying period. The low value of the correlation coefficient $(r=0.02)$ between lysozyme value in the 6 th and 12 th week (there was a significant increase in the latter) reveals that only part of the birds responded with an increase of lysozyme activity. Hence, it can be assumed that in some birds, a disturbance of the physiological balance occurred during the laying period, leading to intensification of defense processes, manifested in increased lysozyme activity.

Analysis of the phenotypic correlation between the values of utility traits and the mean lysozyme activity for the whole laying period revealed a significant negative correlation with the number of eggs and hatchability, and significant positive correlation with the percentage of unhatched poults (Table 3). Analysis of variance (Table 4), in which lysozyme activity for the whole laying period was used as a criterion for allocating the birds into groups, confirmed the unfavourable relationship between lysozyme and the mentioned characters. Turkey hens characterized by the highest average lysozyme activity for the whole laying period were also characterized by the lowest egg production, the lowest hatchability, and the highest percentage of unhatched poults. 
The results of many studies show that non-specific immunity characters should not have a negative effect on utility characters. It was also shown that selection aimed at increasing non-specific immunity in many cases improved production characters (Bassalik-Chabielska, 1983; Mityushnikov and Varakina, 1985; Kostomakhin, 1987; Pavel et al., 1987). These findings, as well as the significant differentiation of lysozyme activity found in our study during the laying period, made it necessary to analyze the relationships between the characters in particular periods of enzyme activity determination. On analyzing the correlation between lysozyme activity in consecutive periods of measurements and its mean activity for the whole period (Table 2), it was found that the correlation coefficient was the highest in the 18 th week $(r=0.72)$. Hence, measurement of lysozyme activity in the 18 th week seems to be the most reliable index of the average activity correlating with the utility traits.

Correlation calculated between values of the analyzed reproductive performances and lysozymc activity in particular periods (Table 5) showed that statistically significant dependencies occurred almost exclusively in the 18th week of the laying period. Correlation coefficients in other periods were low and insignificant. The unfovourable dependence between lysozyme activity and reproductive performance was noticeable in the 12th week, and became significant in the 18th week, after which it decreased to small and insignificant values in the 24 th week of the laying period.

These results suggest that the discussed dependence was short-lasting and could have been due to an increase of lysozyme activity observed mainly in weaker females, who also showed worse reproductive performance.

\section{CONCLUSIONS}

Serum lysozyme activity in turkey hens showed considerable variation during the laying period. In the $18 \mathrm{th}$ week of this period there was a significant negative correlation between serum lysozyme activity and number of eggs hatching from set and fertile eggs, and a significant positive correlation with the percentage of unhatched poults. In the other periods, the correlation between lysozyme activity and reproductive performance indicators was low and statistically insignificant. 


\section{REFERENCES}

Bassalik-Chabielska L., 1983. Studies on inheritance of resistance and methods of selection. In: L. Bassalik-Chabielska (Editor). Genetic immunity of animals to infectious and invasive diseases (in Polish). PWRiL, Warszawa, pp. 175-187

Jankowski J., Prusinowska I., Faruga A., 1994. Preliminary studies on lysozyme activity in turkey blood serum. Proceedings of 9th European Poultry Conference, Glasgow (UK), Vol. 1, 189 - 190

Jollés P., Jollés J., 1984. Whats new in lysozyme rescarch? Always a model system, todeys as yestcrday. Mol. Cell. Biochem. 63,165-189

Kostomakhin N., 1987. The relationship between natural resistance and economic traits in Black Pied Cattle (in Russian). Sel'.- Khoz. Biol.10,100-103

Kowalska M., Rzedzicki J., 1988. Functions of lysozyme in an organism (in Polish). Med. wet. 44, 707-711

Metzger M., 1970. Lysozyme. In: S. Ślopek (Editor). Practical immunology (in Polish). PZWL, Warszawa, pp. 181-189

Mityushnikov V., Varakina R., 1985. Effect of selection on natural disease resistance in layers. Proccedings of 6th International Symposium on Actual Problems of Avian Genetics, Bratislava, pp. 198-202

Pavel Y.G., Fedotovskii A., Valdmam E., 1987. Population immunology and the prediction of viability of fowls (in Russian). Dokl. Vses. Akad. Sel'.- khoz. Nauk. 12, 26-27

\section{STRES7CZFNIE}

\section{Związek między aktywnością lizozymu surowicy krwi i cechami reprodukcyjnymi u indyczek}

Celem badań było określenie dynamiki zmian aktywności lizozymu surowicy u indyczek w okresie nieśności oraz ustalenic współzalcżności między aktywnością lizo»ymu i cechami użytkowymi. Materiał stanowiło 107 losowo wybranych indyczek z rodu matecznego żeńskiego (J-44) selekcjonowanego na zwiększenie nieśności. Aktywność lizozymu określono cztcrokrotnic w 6 , 12, 18, 24 tygodniu nieśności. Stwierdzono wysoce istotny wzrost aktywności lizozymu w 12 tygodniu i stopniowy, niewielki spadek w następnych tcrminach. W 18 tygodniu nieśności stwierdzono istotną ujemną korelację między aktywnością lizozymu a liczbą zniesionych jaj i wylęgiem piskląt oraz istotną dodatnią korelację z procentem piskląt niewyklutych. W pozostalych terminach współzależność aktywności lizozymu z wartością cech reprodukcyjnych była niska i statystycznic nicistotna. 